\title{
COVID-19 and Plasmodium ovale Malaria: A Rare Case of Co-Infection
}

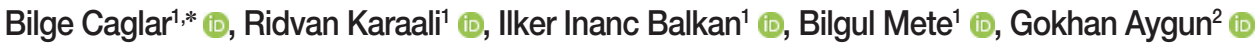 \\ ${ }^{1}$ Department of Infectious Diseases and Clinical Microbiology, Istanbul University-Cerrahpasa, Cerrahpasa Faculty of Medicine, Istanbul, Turkey; \\ ${ }^{2}$ Department of Microbiology, Istanbul University-Cerrahpasa, Cerrahpasa Faculty of Medicine, Istanbul, Turkey
}

\begin{abstract}
The COVID-19 pandemic continues to be a major health problem worldwide. Timely diagnosis of co-infections mimicking COVID-19, such as malaria, might be challenging particularly in non-endemic areas. We report the first case of COVID-19 and Plasmodium ovale malaria co-infection from our region aiming to highligt the importance of travel history and prophylaxis in malaria management in the context of pandemic. The galloping sound can sometimes be a harbinger of zebra besides the horse.
\end{abstract}

Key words: Plasmodium ovale, COVID-19, malaria, artesunate, SARS-CoV-2

\section{INTRODUCTION}

The COVID-19 pandemic, which has left 19 months behind, continues to affect all aspects of life worldwide. Turkey ranks 9th in terms of the total number of cases in the world [1]. As the attention is focused entirely on the pandemic disease, difficulties may be experienced in the timely diagnosis of co-infections. While the diagnosis of malaria is already elusive in a non-endemic country, this difficulty appears to be further increased due to the similarity of symptoms and findings with COVID-19 [2]. For the last 10 years, only imported cases of malaria have been reported from Turkey. Imported plasmodium ovale is rarely reported as alone or an agent of mixed infection in travelers returning from Africa and accounts for $2.4 \%$ of the whole cases, while the rest are due to P. falciparum and P. vivax $[3,4]$.

Malaria and COVID-19 have similar clinical aspects and both may negatively affect the course of each other [5-8]. While a severe course of malaria is not expected from Plasmodium ovale, findings of organ failure may occur due to the temporarily impaired immunity by COVID-19 and the relatively increased parasite burden due to the delay in diagnosis.

We present here a case of COVID-19 and imported P. ovale

- Received 2 May 2021, revised 21 July 2021, accepted 26 July 2021.

*Corresponding author (bilge_cglr1907@hotmail.com)

(c) 2021. Korean Society for Parasitology and Tropical Medicine

This is an Open Access article distributed under the terms of the Creative Commons

Attribution Non-Commercial License (https://creativecommons.org/licenses/by-nc/4.0) which permits unrestricted non-commercial use, distribution, and reproduction in any

medium, provided the original work is properly cited. malaria co-infection and aim to demonstrate how these 2 infections interact with each other, both diagnostically and clinically.

\section{CASE DESCRIPTION}

A 38-year-old male patient without any co-morbid disease admitted with fatigue and fever for 7 days. He was diagnosed as COVID-19 with a positive SARS-CoV-2 PCR test and was given favipiravir as antiviral and enoxaparine as anticoagulant, according to national guidelines [9], 5 days prior to his admission to our center. His symptoms were not resolved despite antiviral treatment. He described a 5 days business journey to Ghana, a West African country, 8 days prior to his symptoms. He did not receive anti-malarial prophylaxis. On physical examination; his body temperature was $37.9^{\circ} \mathrm{C}$, blood pressure $110 / 70 \mathrm{mmHg}$, respiratory rate $20 / \mathrm{min}$ and oxygen saturation was $98 \%$ in ambient air. No other pathological finding was detected. Laboratory tests revealed; CRP: $53 \mathrm{mg} / \mathrm{L}(0-5 \mathrm{mg} / \mathrm{L})$ procalcitonin: $0.083 \mathrm{ng} / \mathrm{ml}(0-0.5 \mathrm{ng} / \mathrm{ml})$ AST: $21 \mathrm{IU} / \mathrm{L}$, ALT: 28 IU/L, LDH: 309 IU/L, Ferritin: 1,219 ng/ml, D-dimer: 1.2

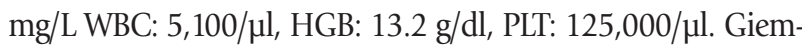
sa stained blood smear for malaria and rapid antigen test for $P$. falciparum and $P$. vivax were negative. His chest computerized tomography (CT) revealed ground glass opacities in bilateral lungs, compatible with Covid-19. Control nasopharyngeal swab PCR was positive for SARS-CoV-2.

He was evaluated as hyperinflammatory syndrome secondary to COVID-19, favipiravir treatment was extended for an- 
other 5 days, vitamin D 20,000 U/day and colchicine $0.5 \mathrm{mg}$ q8h po were initiated for immunomodulation and daily dose of enoxaparin-sodium was increased to 4,000 U sc q12 hr.

As his fever continued $\left(>38^{\circ} \mathrm{C}\right)$ on the third day of followup he was hospitalized for further evaluation and treatment. His physical examination was normal and he was hemodynamically stable while laboratory tests revealed deterioration as follows; CRP: $241 \mathrm{mg} / \mathrm{L}$ procalcitonin: $18 \mathrm{ng} / \mathrm{ml}$, AST: 148 IU/L, ALT: 224 IU/L, LDH: 1,019 IU/L, direct bilirubin: 0.37 mg/dl, Ferritin: >2,000 ng/ml, D-dimer: $3.3 \mathrm{mg} / \mathrm{L}, \mathrm{WBC}$ :

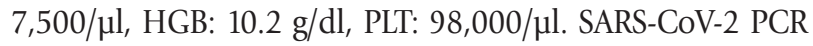
was detected negative. Peripheral blood smear was obtained due to continued fever and intra-erythrocyte trophozoites with typical stony ring appearance and schizonts in maturation stage were detected (Fig. 1).

He was diagnosed as complicated malaria, his blood sample was sent to National Reference Parasitology Laboratory for species level identification with molecular methods and was given intravenous artesunate $2.4 \mathrm{mg} / \mathrm{kg}$ at $0,12,24,48,72$, 96 , and $120 \mathrm{hr}$, as recommended in the guidelines [10]. Colchicine was discontinued. The patient's symptoms were resolved within the $24 \mathrm{hr}$ of treatment, blood platelet count returned to normal, control blood smears became negative. Liver function tests and acute phase reactants tended to regress. After 5 days of iv artesunate treatment, he was switched to oral artemeter lumefantrine which was given for 3 days. Daily blood smears remained negative and laboratory tests on day 8 were normal as follows; CRP: 1.58 mg/L AST: 15 IU/L, ALT: 49 IU/L, LDH: $267 \mathrm{IU} / \mathrm{L}$, direct bilirubin: $0.17 \mathrm{mg} / \mathrm{dL}$, D-dimer: 0.51

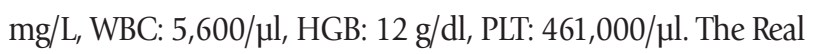
Time PCR test result revealed Plasmodium ovale. After confirming that the blood G6PD level was normal, he was discharged

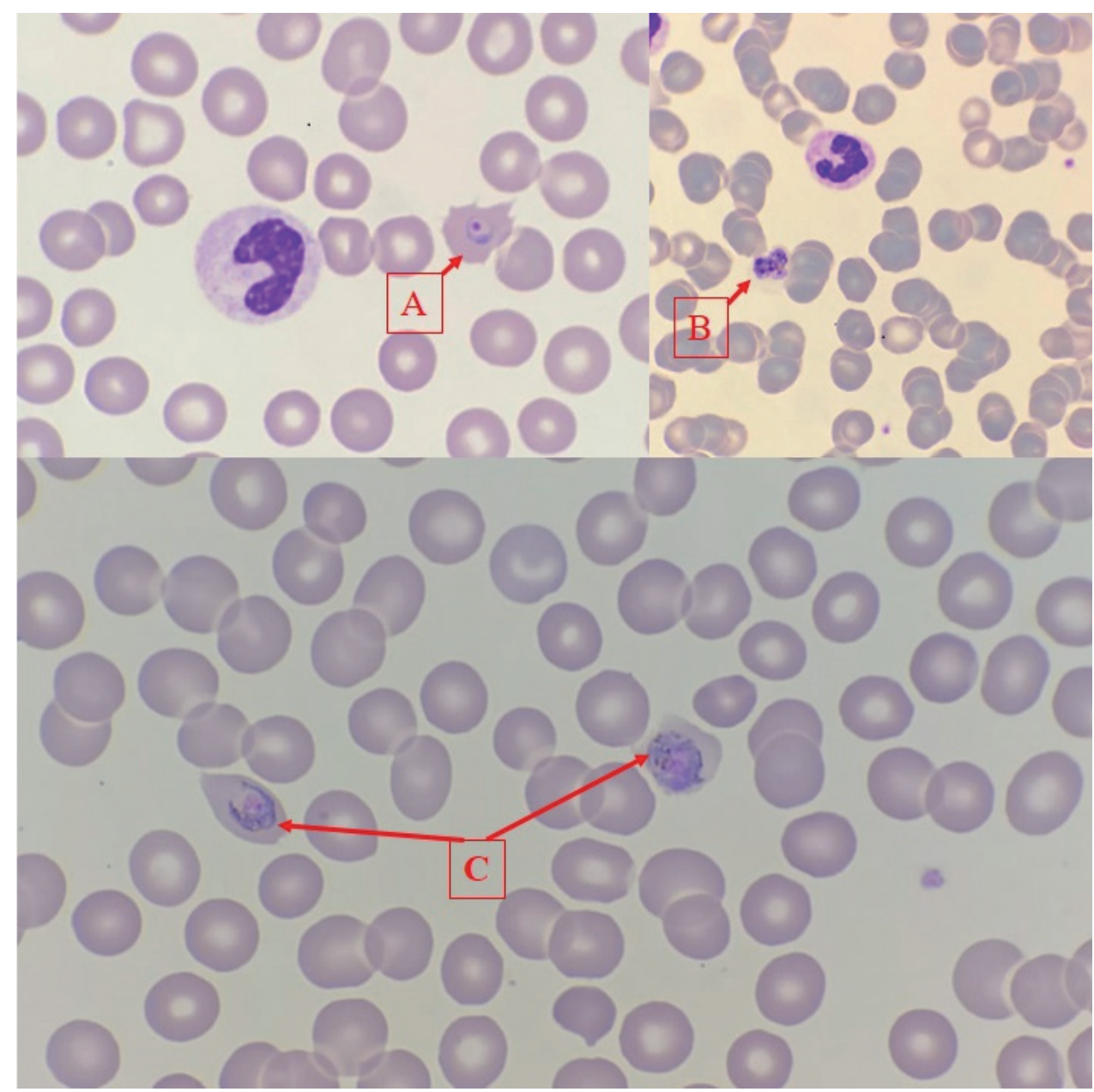

Fig. 1. (A) Intra-erythrocytic trophozoite, (B) Mature schizont, (C) Intra-erythrocytic immature schizont indicating Plasmodium ovale. 
with a prescription of 2-week primaquine for hypnozoite-acting treatment to prevent relapses.

\section{DISCUSSION}

This report covers the first case of COVID-19 and Plasmodium ovale malaria co-infection detected in our region. By presenting this case, we aimed to draw attention to a rare travelrelated infection masked by a pandemic infection. Misinterpretation of patients with similar clinical and laboratory findings as COVID-19 infection is common, in the pandemic setting. Malaria symptoms and signs are similar to COVID-19. Both diseases can also fever, myalgia, fatigue, headaches, gastrointestinal symptoms and cytokine storm. It becomes more challenging when COVID-19 is confirmed with positive PCR test and typical radiological findings, while the screening tests for the concomitant infection are negative, as in our case. It is of vital importance to complete the differential diagnostic work-up particularly in case of deterioration despite treatment.

COVID-19 can lead to cytokine storm, which is responsible for the more severe manifestations of the disease.Cytokine response associated with systemic illness has been postulated to induce vivax malaria relapses. [11]. The clinical deterioration of the patient with ongoing fever, increasing CRP, ferritin, $\mathrm{LDH}$, transaminase levels and decreasing PLT counts in the second week were attributed to cytokine storm due to COVID-19 and favipiravir related liver toxicity at first. However increasing procalcitonin and decreasing hemoglobin levels in the course led us consider severe falciparum malaria which was initially screened as negative. Procalcitonin has been reported among indicators of severe falciparum malaria [12].

At that point, intravenous treatment with arthesunate was initiated before confirmation of the malaria in species level. The response to the treatment was dramatic in the first day owing to the low level of parasitemia, specific to non-falciparum malaria. The case was not categorically "severe malaria" but was complicated with a systemic viral co-infection.

Travel history remains important in the differential diagnosis even in pandemic conditions. Malaria must be considered first in patients returning from endemic regions. Ghana is a malaria-endemic West African country, P. falciparum being the most prevalent species with a prevalence of $98 \%$ while $P$. ovale accounts for the $1 \%$ of the cases [13].

Our case once again demonstrates the importance of malaria prophylaxis. If the patient had received prophylaxis for ma- laria during his travel to Ghana, he could have both protected from malaria and could have a less severe course of COVID-19. Hence there are studies showing that atovaquone/ proguanil, which is routinely recommended and provided for malaria prophylaxis in Turkey, is somehow effective against SARS-CoV-2 virus [14,15].

Pandemic SARS-CoV-2 infection may mask malaria in returning travelers. Diagnosing non-falciparum and non-vivax malaria is relatively more elusive due to low parasitemia in blood smear and negativity in routine rapid antigen tests. Molecular testing is recommended for confirmation. The galloping sound can sometimes be a harbinger of zebra besides the horse.

\section{CONFLICT OF INTEREST}

The authors declare that they have no conflicts of interest.

\section{REFERENCES}

1. Worldometer. Report Coronavirus Cases [Internet]; [cited 2021 Feb 7]. Available from: https://www.worldometers.info/ coronavirus/\#countries

2. World Health Organization. Vector-borne and parasitic diseasesMalaria-Turkey [Internet]; [cited $2021 \mathrm{Feb}$ 7]. Available from: https://www.euro.who.int/en/health-topics/communicable-diseases/vector-borne-and-parasitic-diseases/malaria/countrywork/turkey\#: :text=Malaria\%20risk\%20exists\%20only\%20 in,areas\%20where\%20tourism\%20is\%20concentrated

3. Beşli Y, Bengür FB, Akyar I, Kurt Ö. The investigation of malaria cases in a central laboratory in İstanbul region for a period of fifteen years. Turkiye Parazitol Derg 2019; 43: 65-69. https://doi. org/10.4274/tpd.galenos.2018.5939.

4. Delıbaş SB, Akisü C, Aksoy U, Ozkoç S, Sari B, Tekış D, Bıberoğlu K. Plasmodium falciparum ve Plasmodium ovale'nin Etken Olduğu İmporte Bir Miks Sitma Olgusu. Turkiye Parazitol Derg 2005; 29: 63-67 (in Turkiye).

5. Di Gennaro F, Marotta C, Locantore P, Pizzol D, Putoto G. Malaria and COVID-19: common and different findings. Trop Med Infect Dis 2020; 5: 141. https://doi.org/10.3390/tropicalmed5030141

6. Correia MJ, Frade L, Guerreiro R, Araujo I, Baptista T, Fonseca C, Mansinho K. A patient with severe malaria and COVID-19: how do you tell the difference between these infections? Eur J Case Rep Intern Med 2020; 7: 002007. https://doi.org/10.12890/2020_ 002007

7. Sardar S, Sharma R, Alyamani TYM, Aboukamar M. COVID-19 and Plasmodium vivax malaria co-infection. IDCases 2020; 21: e00879. https://doi.org/10.1016/j.idcr.2020.e00879

8. Hussein MIH, Albashir AAD, Elawad OAMA, Homeida A. Ma- 
laria and COVID-19: unmasking their ties. Malar J 2020; 19 : 457. https://doi.org/10.1186/s12936-020-03541-w

9. COVID-19 Bilgilendirme Platformu. Erişkin Hasta Tedavisi [Internet]; [cited $2021 \mathrm{Feb} 7]$. Available from: https://covid19.saglik.gov.tr/TR-66926/eriskin-hasta-tedavisi.html

10. World Health Organization. Guidelines for the Treatment of Malaria. 3rd ed. Geneva, Switzeland. World Health Organization. 2015, pp. 1-313. https://apps.who.int/iris/handle/10665/162441

11. White NJ. Determinants of relapse periodicity in Plasmodium vivax malaria. Malar J 2011; 10: 297 https://doi.org/10.1186/1475-287510-297

12. Amoah LE, Donu D, Abuaku B, Ahorlu C, Arhinful D, Afari E, Malm K, Koram KA. Probing the composition of Plasmodium species contained in malaria infections in the Eastern region of
Ghana. BMC Public Health 2019; 19: 1617. https://doi.org/10. 1186/s12889-019-7989-1

13. Hollenstein U, Looareesuwan S, Aichelburg A, Thalhammer F, Stoiser B, Amradee S, Chullawichit S, El Menyawi I, Burgmann H. Serum procalcitonin levels in severe Plasmodium falciparum malaria. Am J Trop Med Hyg 1998; 59: 860-863. https://doi. org/10.4269/ajtmh.1998.59.860

14. Seyahat Sağlığı. Health status of countrie [Internet]; [cited 2021 Feb 8]. Available from: https://www.seyahatsagligi.gov.tr

15. Yang CW, Peng TT, Hsu HY, Lee YZ, Wu SH, Lin WH, Ke YY, Hsu TA, Yeh TK, Huang WZ, Lin JH, Sytwu HK, Chen CT, Lee SJ. Repurposing old drugs as antiviral agents for coronaviruses. Biomed J 2020; 43: 368-374. https://doi.org/10.1016/j.bj.2020.05.003 